九州大学学術情報リポジトリ

Kyushu University Institutional Repository

Ecological Studies on Formica yessensis Forel, with Special Reference to Its Effectiveness as a Biological Control Agent of the Pine Caterpillar Moth in Korea : I. Geographical and Ecological Distributions of Formica yessensis Forel (Hymenoptera : Formicidae)

Kim, Chang Hyo

Division of Insect Natural Enemies, Institute of Biological Control, Faculty of Agriculture, Kyushu University

Murakami, Yozo

Division of Insect Natural Enemies, Institute of Biological Control, Faculty of Agriculture, Kyushu University

https://doi.org/10.5109/23713

出版情報: 九州大学大学院農学研究院紀要. 24 (4)，pp.239-245，1980-02. Kyushu University バージョン：

権利関係 : 


\title{
Ecological Studies on Formica yessensis Forel, with Special Reference to Its Effectiveness as a Biological Control Agent of the Pine Caterpillar Moth in Korea \\ I. Geographical and Ecological Distributions of Formica yessensis Forel (Hymenoptera : Formicidae)
}

\author{
Chang Hyo Kim* and Yôzô Murakami \\ Division of Insect Natural Enemies, Institute of Biological Control, \\ Faculty of Agriculture, Kyushu University 46-13, Fukuoka 812
}

(Received November 13, 1979)

\begin{abstract}
Formica yessensis occurs in southwestern Hokkaido, Honshu north of Hakone-Fuji Mountains, Korea (except Jeju-Do unsurveyed), Ussuri and northeastern China. In Hokkaido and Tohoku Province of Honshu it occurs from sea shore areas to mountains as high as $700 \mathrm{~m}$, while in central Honshu at $700-1800 \mathrm{~m}$ in altitude. A record from northern Kyushu is very doubtful. The southern limit of its distribution is nearly $35^{\circ} \mathrm{N}$ both in Korea and Japan. However, the ant inhabits lower lands even at the southern limit in Korea, while only mountains as high as $1500 \mathrm{~m}$ at the southern limit in Japan. In Korea, favourable habitat of the ant is the red pine forest, whereas it is rather open land adjacent to forest margin in Japan.
\end{abstract}

\section{INTRODUCTION}

Formica (Formica) yessensis Forel has been noticed as a possibly important natural enemy of the pine caterpillar moth, Dendrolimus spectabilis Butler in Korea (Teranishi, 1916), and it has been generally believed that the injury by the moth is extremely low in the pine forests where the ant inhabits. However, the researches on the biology and ecology of the ant in Korea and on the role of the ant as a natural biological control agent were not undertaken before the senior author and his collaborators worked on the subject (Kim and Kim, 1973; Kim and Choi, 1976; Kim, 1977; Kim et al., 1978).

Since 1972, the senior author has been engaged in the biological control study of the pine caterpillar moth by utilizing $F$. yessensis in red pine forests in Gyeongsang-Nam-Do, Korea. From 1978 to 1979, he carried out the investigation on the geographical and ecological distributions of the ant in Japan and Jeonlla-Nam-Do, Korea cooperated with the junior author. The present paper reports the results of their investigations on the geographical and ecological distributions of $F$. yessensis, especially in Korea and Japan.

\section{PAST RECORDS AND SOME COMMENTS}

$F$. yessensis has been recorded from Japan, Korea, Formosa, China, Ussuri

* Present address: Gyeongsang National University, Jinju 620, Korea. 
Table 1. Geographical distribution records of $F$. (F.) yessensis in the world.

\begin{tabular}{|c|c|c|}
\hline Province & Locality & Authority \\
\hline Hokkaido & $\begin{array}{l}\text { Sorachi } \\
\text { Sapporo, Jozankei and Obihiro } \\
\text { Fukushima and Matsumae } \\
\text { Kutchan and Hakodate } \\
\text { Ishikari Shore } \\
\text { Mt. Apoi ( } 500-700 \mathrm{~m} \text { alt.) }\end{array}$ & $\begin{array}{l}\text { Forel (1901) } \\
\text { Teranishi }(1929) \\
\text { Morisita (1945b) } \\
\text { Hayashida (1964) } \\
\text { Ito (1971) } \\
\text { Hayashida (1971) }\end{array}$ \\
\hline Honshu & $\begin{array}{l}\text { Niigata, Nagano and Fukushima Prefs. } \\
\text { Iwate Pref. } \\
\text { North of Chûbu-mountains } \\
\text { Norikura (lower than } 1700 \mathrm{~m} \text { alt.) } \\
\text { Chûbu-mountains ( } 700-1700 \mathrm{~m} \text { alt.) } \\
\text { Hakone (Mt. Kintoki) } \\
\text { Hakkoda ( } 500-600 \mathrm{~m} \text { alt.) } \\
\text { Shiga Heights (1400-1650 m alt.) } \\
\text { Mt. Fuji (1500 m alt.) } \\
\text { Miyagi Pref. (Oshika Pen.) } \\
\text { Norikura Heights (1200-1800 m alt.) } \\
\text { Miyagi Pref. (Mt. Izumigatake, Mt Kitaizumigatake, } \\
\text { Okunikkawa, Aobayama, Kitasendai, Kunimi and } \\
\text { Mt. Taihakusan) }\end{array}$ & $\begin{array}{l}\text { Yano (1912) } \\
\text { Teranishi (1929) } \\
\text { Teranishi (1934) } \\
\text { Morisita (1940) } \\
\text { Morisita (1945a) } \\
\text { Kondoh (1961) } \\
\text { Yasuno (1963) } \\
\text { Kondoh (1967) } \\
\text { Kubota (1970) } \\
\text { Sonobe (1973) } \\
\text { Kondoh (1976) } \\
\text { Sonobe (1977a) }\end{array}$ \\
\hline $\begin{array}{l}\text { Kyushu } \\
\text { Korea }\end{array}$ & $\begin{array}{l}\text { Northern Kyushu (?) } \\
\text { Seoul } \\
\text { Suweon, Hwasan and Mt. Gumgang } \\
\text { Mt. Pakyon }\end{array}$ & $\begin{array}{l}\text { Sonobe }(1977 \mathrm{~b}) \\
\text { Teranishi }(1916) \\
\text { Teranishi }(1929) \\
\text { Collingwood }(1976)\end{array}$ \\
\hline Siberia & Tomsk and Tobolsk (?) & Emery (1909) \\
\hline Ussuri & Possjet Bay & Karawajew (1929) \\
\hline China & Luan-ping & Teranishi (1936) \\
\hline Formosa & Mt. Nanhutashan (?) & Wheeler (1933) \\
\hline
\end{tabular}

and Siberia (Table 1).

In Japan it has been recorded from Hokkaido, Honshu and Kyushu. In Hokkaido the record is limited in the southwestern part. In the northeastern Hokkaido it is replaced by another closely related species, Formica (Formica) truncorum Fabricius (Sonobe, 1977b). Studies on the vertical distribution in Hokkaido revealed that it occurred from sea shore areas such as Cape Shirakami (Morisita, 1945b) and Ishikari Shore (Ito, 1971) to mountain areas such as Umanose $(500-700 \mathrm{~m}$ ), Mt. Apoi, southern part of the Hidaka Mountains (Hayashida, 1971).

In Tohoku Province of Honshu, it occurs also from sea shore areas such as Oshika Peninsula in Miyagi Prefecture (Sonobe, 1977a) to mountain areas such as Kayano grassland $(510-540 \mathrm{~m})$, Mt. Hakkoda, Aomori Prefecture (Yasuno, 1963). On the other hand, in central Honshu it occurs only north of Mt. Fuji (Kubota, 1970) and Mt. Kintoki, Hakone (Kondoh, 1961), and at 700-1800 $\mathrm{m}$ altitude; e.g., Shiga Heights at $1400-1650 \mathrm{~m}$ (Kondoh, 1967), Norikura Heights at $1200-1800 \mathrm{~m}$ (Kondoh, 1976) and Mt. Fuji at about $1500 \mathrm{~m}$ (Kubota, 1970). Morisita (1945a) recorded $F$. yessensis from the elevation of $700-1700 \mathrm{~m}$ in the Central Alpine Area in Honshu. It has not been recorded from southwestern parts of Honshu nor Shikoku (Okamoto, 1978).

There is, however, a peculiar record of $F$. yessensis in northern Kyushu (Sonobe, 1977). By the personal letter of Mr. R. Sonobe to the junior author it was revealed that the record was based on the specimen collected by $\mathrm{Mr}$. 
M. Goto in "Hiratani Spa, Kashima-shi, Saga Prefecture on June 9, 1974”. In order to confirm the occurrence of the ant the authors surveyed intensively the area of Hiratani Spa and its vicinity on June 10,1979, but they could not find any trace of nest nor worker ants. Since the locality in question is about $370 \mathrm{~m}$ in altitude and since it occurs in places higher than $700 \mathrm{~m}$ even in central Honshu, the authors concluded that the record from Kyushu was based on the specimen erroneously labelled (Murakami and Kim, in press).

Teranishi (1916) first recorded in Korea the occurrence of $F$. yessensis based on the specimen collected in Seoul by Mr. S. Yamamura, and afterwards from Mt. Reugi in Suweon, Hwasan and Mt. Gumgang (Teranishi, 1929). D. Y. Kim (1968) recorded "Formica rufa (L.)" as a predator of the pine caterpillar moth in Jeonlla-Bug-Do, but since $F$. rufa occurs only in Europe it should be corrected as $F$. yessensis. Recently Collingwood (1976) recorded $F$. yessensis from Mt. Pakyon, Kaesong Province based on specimens collected in a deciduous forest.

On the other hand, Wheeler (1933) recorded it from Formosa based on the specimens collected by Mr. J. Sonan (=Minamikawa) on Mt. Nanhutashan ("Nankataigan" by Wheeler). As he stated that it was really intermediate between approximans Wheeler and sinensis Wheeler, i.e., the dorsal surface of the head and thorax being less hairy than in approximans and the typical truncorum Fabricius and the tibiae without oblique hairs as in yessensis and sinensis, it is doubtful whether the Formosan form is true yessensis or not. Although the altitude of the top of Mt. Nanhutashan is $3798 \mathrm{~m}$, that of the point where the very specimens were collected is unknown.

Also, $F$. yessensis was recorded from Luan-ping, $130 \mathrm{~km}$ northeast from Peking in China (Teranishi, 1939). Emery (1909) recorded it from Tomsk and Tobolsk in Siberia, but according to Collingwood (1976) Siberian specimens named $F$. yessensis were synonymised as Formica (Formica) lugubris Zett. by Dlussky (1967). The specimens, however, recorded from Ussuri by Karawajew (1929) could be possibly real yessensis because the locality collected is rather closer to Chinese and Korean habitats.

\section{SURVEY IN KOREA AND JAPAN}

The authors recognized the occurrence of $F$. yessensis in following districts in Korea and Japan.

Korea: Gyeongsang-Nam-Do - Sancheung ( $460 \mathrm{~m}$ in altitude), Mt. Jiri ( 815 $\mathrm{m})$, Euleung $(420 \mathrm{~m})$, Jinseung $(300 \mathrm{~m})$, Jinyang $(350 \mathrm{~m})$, Cheungkok Temple (410 $\mathrm{m})$, Munsan $(250 \mathrm{~m})$, Gonyang $(300 \mathrm{~m})$, Sacheun $(200 \mathrm{~m})$, Guam $(300 \mathrm{~m})$, Hadong $(350 \mathrm{~m})$, Goseung $(210 \mathrm{~m})$, Namhae $(50 \mathrm{~m})$, Geujedo $(70-200 \mathrm{~m})$; Jeonlla-NamDo - Mt. Mudungsan ( $400 \mathrm{~m})$.

Japan: Hokkaido - Ishikari Shore (0 m), Misumai (Sapporo) (100 m); Honshu - Norikura Heights $(1300 \mathrm{~m})$, Mt. Nyukasa (Takato, Nagano Pref. ) (1300 $\mathrm{m})$.

In addition, the junior author examined specimens of his own and those preserved in the Entomological Laboratory, Kyushu University, and found 
more specimens of $F$. yessensis collected from following localities.

Korea: Hamgyeong-Bug-Do - 1 worker, Musan (labelled as "Enjômen, Mozangun, Kankyôhokudô, N. Korea, 8. vi. 1939, T. Hirao”). Hamgyeong-Nam-Do -43 workers, Anbyeon (labelled as "Anpen-gun, Kankyônando, N. Korea, 29. x. 1939, S. Kumashiro"). Seoul -31 workers, Namsan (labelled as "Nanzan, Keijo, Korea, 23.viii.1940, T. Shirôzu"). Chungcheung-Nam-Do - 2 workers, Kongju (labelled as "Seian-men, Kôshû-gun, Chûseinan-dô, C. Korea, viii.1939, K. S. Ryû").

Japan : Hokkaido - 6 workers, Maruyama (labelled as "Maruyama, Sapporo, 11.vi.1956, K. Hayashida"); 20 workers, Tsukisappu (labelled as "Tsukisappu near Sapporo, 15.vii.1955, Y. Murakami"); 5 workers, Jozankei (labelled as "Jozankei near Sapporo, 30.vi.1958, Y. Murakami”); 1 worker, Jozankei (labelled as “Zyozankei, Ishikari, 10.vii.1960, S. Nakao"). Honshu - 10 workers, Mt. Aokiyama (Aizu-Wakamatsu) (labelled as "Mt. Odayama, Iwashiro, 19.v.1946, Y.

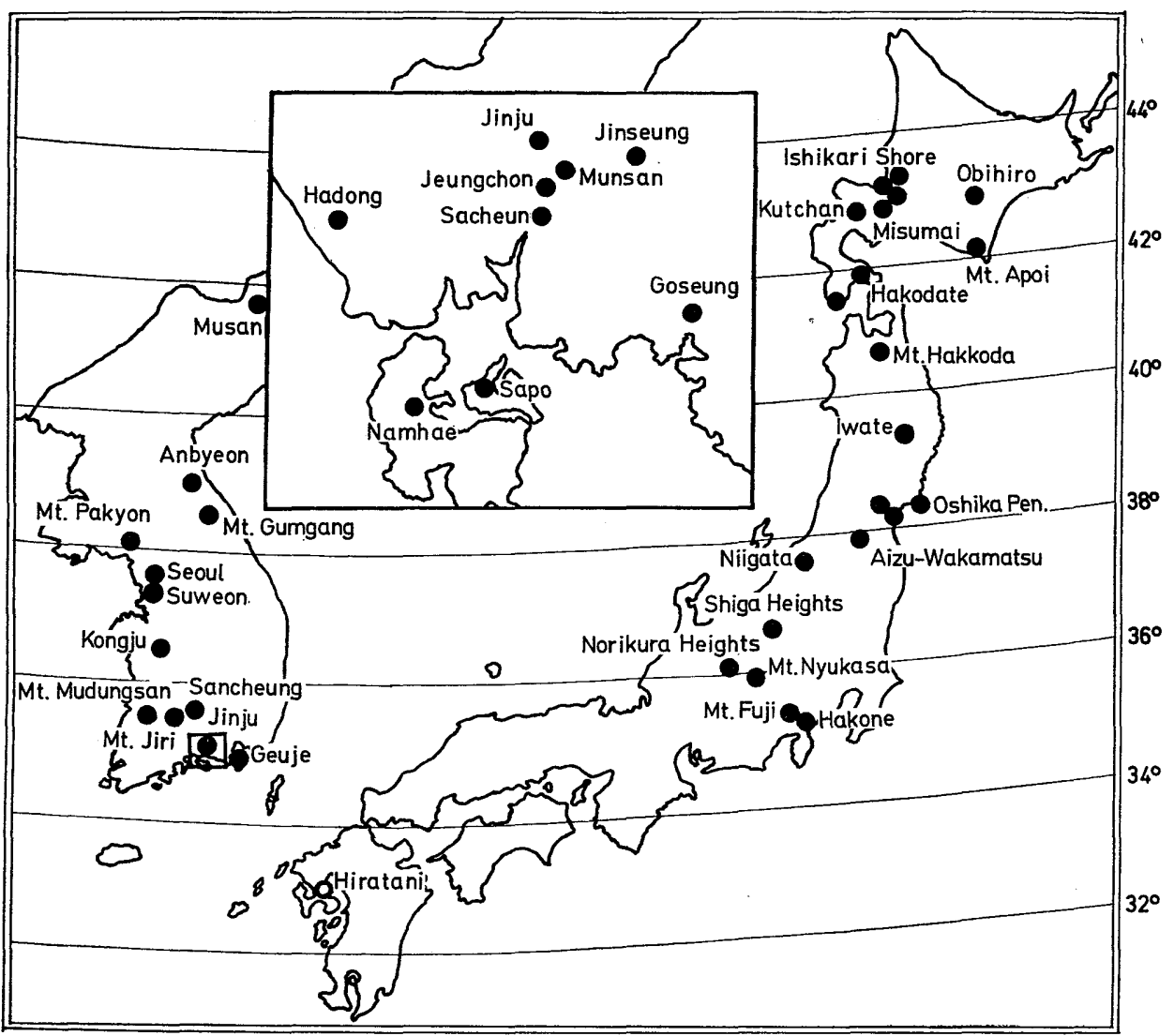

Fig. 1. Geographical distribution map of $F$. $(F$.$) yessensis in Korea and$ Japan. Solid circles refer to the localities having been recorded and newly recorded, and open circle refers to the locality recorded but doubtful. 
Kurosawa”) ; 1 worker, Sawa (Aizu-Wakamatsu) (labelled as “Sawa, Iwashiro, 24.v.1946, Y. Kurosawa").

Fig. 1 shows the distribution map of $F$. yessensis in Korea and Japan. According to this map, the ant distributes throughout Korea (except Jeju-Do uninvestigated), southern Hokkaido and Honshu north of Hakone-Fuji Mountains. Comparing the specimens collected from Korea and Japan, the authors concluded that there is no morphological difference between them. The southern limits of this ant both in Korea and Japan are approximately $35^{\circ} \mathrm{N}$. However, at the southern limits of this ant, it occurs even in low lands such as Geujedo $(70-200 \mathrm{~m})$ and Namhae $(50 \mathrm{~m})$ in Korea, while it is found only on high mountains (at least about $1500 \mathrm{~m}$ ) in Japan.

Ecologically, $F$. yessensis usually inhabits red pine forests in Korea, whereas it prefers grassland close to the forest margin in Japan. In Ishikari Shore the nests are mostly confined within the grassland occupied by eulalia, sweet brier and vines with moderately dense plant matrix, while absent both in sparse shore side vegetation and thick inland oak forest. Sufficient light intensity and presence of suitable nest cores are regarded as the factors principally responsible for their relative abundance as stated by Ito (1971). Hayashida (1957) also suggested $F$. yessensis preferred a certain degree of shade, and the best nest site was around the root of living trees with relatively shady and moist conditions (Hayashida, 1960). Sometimes the nests distribute in sparse secondary forests of the white birch and other deciduous trees (Morisita, 1945). Usually, the densities of trees in forests within the range of $F$. yessensis is observed too high for this ant to establish its nest in Japan, while in Korea the red pine trees are relatively sparse in forests, therefore sufficient light intensity provides a favourable condition for nesting.

\section{ACKNOWLEDGEMENT}

The authors wish to express their hearty thanks to Professor Y. Hirashima for his constant guidance and kindness in reading through this manuscript as well as for giving them the opportunity to examine the specimens preserved in the Entomological Laboratory, Kyushu University. In the course of field investigations in Korea, the senior author is indepted to Dr. Jin Sik Choi, Mr. Jong-Man Kim, Mr. Sok Hyon Kim and Mr. Bu-Gun Jeung of Gyeongsang National University for their kind cooperation. Also, his hearty thanks are due to Dr. Tae-Gyu Yoon, President of the University, for his help promoting the present study and encouragement.

\section{REFERENCES}

Collingwood, C. A. 1976 Ants (Hymenoptera, Formicidae) from North Korea. Ann. Hist. -nat. Mus. Nat. Hung., $68: 295-309$

*Dlussky, G. M. 1967 Ants of the Genus Formica. Izdatel'stvo Nauka, Moskow (in Russian)

Emery, C. 1909 Beiträge zur Monographie der Formiciden des paläarktischen Faunengebietes. VII. Deutsch. Ent. Zeits., 1909: 179-204 
Forel, A. 1901 Formicidae des Naturhistorischen Museums in Hamburg. Mitt. Naturh. Mus. Hamb., 18: 43-82

Hayashida, K. 1957 Ecological distribution of ants in Sapporo and vicinity (Preliminary report). J. Fac. Sci., Hokkaido Univ., Ser. VI, Zool., 13: 173-177

Hayashida, K. 1960 Studies on the ecological distribution of ants in Sapporo and vicinity (1 et 2). Insectes Sociaux, $7: 125-162$

Hayashida, K. 1964 Studies on the ecological distribution of ants in Kutchan and its adjacent area. J. Sapporo Otani Jun. Coll., 2: 107-129

Hayashida, K. 1971 Vertical distribution of ants in southern part of the Hidaka Mountains. Mem. Nat. Sci. Mus., 4: 29-38 (in Japanese with English summary)

Ito, M. 1971 Nest distribution of Formica yessensis Forel in Ishikari Shore, in reference to plant zonation. J. Fac. Sci., Hokkaido Univ., Ser. VI, Zool., 18: 144-154

Karawajew, B. 1929 Myrmekologische Fragmente II. Acad. Sci. Ukraine, 13: 205-218

Kim, Chang Hyo 1977 On the polymorphism in a polydomous red wood ant, Formica rufa truncicola var. yessoensis Forel in Korea. Kor. J. Pl. Prot., 16: 105-113 (in Korean with English summary)

Kim, Chang Hyo and Jin Sik Choi 1976 Studies on the biological control of pine caterpillar (Dendrolimus spectabilis Bulter) by red wood ant (Formica rufa truncicola var. yessoensis Forel). Kor. J. Pl. Prot., 15: 7-16 (in Korean with English summary)

Kim, Chang Hyo, Jin Sik Choi and Sok Hyon Kim 1978 Studies on the biological control of pine caterpillar (Dendrolimus spectabilis Butler) by red wood ant (Formica rufa truncicola var. yessoensis Forel). J. Inst. Agr. Resource Utıl., Gyeongsang Univ., 12: 91-123 (in Korean with English summary)

Kim, Chang Hyo and Jong-Man Kim 1973 Studies on red wood ant (Formica sp.) for the control of pine caterpillar (Dendrolimus spectabilis Butler). J. Kor. Pl. Prot., 12: 109-114 (in Korean with English summary)

Kim, Doo Young 1968 A study on natural enemy of Dendrolimus spectabilis Butler in Korea. J. Aomori-ken Biol. Sci., 10:40-43 (in Japanese)

Kondoh, M. 1961 Ants from Hakone Region. Bull. Nat. Hist. Soc. Hakone, 1: 16-27, 3 pls. (in Japanese with English summary)

Kondoh, M. 1967 Ants from Shiga Heights. JIBP-PTS Research Data for 1967: 1-15 (in Japanese, mimeographing)

Kondoh, M. 1976 The ecological distribution of ants at the eastern slope of Mt. Norikura. In "Nature and Culture at Norikura (The Reports of Scientific Investigations)," ed. by Norikura Scientific Investigation Committee, Nagano Pref., pp. 159-172 (in Japanese with English summary)

Kubota, M. 1970 Ant fauna of Mt. Fuji. JIBP, JPTS-SI, Ants, no. 7: 4-7 (in Japanese, mimeographing)

**Morisita, M. 1940 Red wood ants in Mt. Norikura. Yamagoya, 106: 53-59 (in Japanese)

Morisita, M. 1945a Ants. In “Insects," Vol. 2, ed. by H. Furukawa, Kenkyusha, Tokyo, pp. 1-56 (in Japanese)

Morisita, M. 1945b Ants on the southernmost of Hokkaido. Mushi, 16: 21-28 (in Japanese)

Morisita, M. 1979 Synthesis of Dr. M. Morisita's Papers in Ecology, Vol. 1. Shisakusha, Tokyo (in Japanese)

Okamoto, H. 1978 Ants from Kochi Prefecture. The Nature and Insects, 13(10): 24-27 (in Japanese)

Sonobe, R. 1973 Ant fauna of the Kinkasan Island. Annu. Rep. JIBP-CTS for 1972: 178-183 (in Japanese with English summary)

Sonobe, R. 1977a Ant fauna of Miyagi Prefecture, Japan. Jap. J. Ecol., 27: 111-116

Sonobe, R. 1977b Formicidae of Japan (3) Genus Formica Linnaeus. Ari, 8: 1-2 (in Japa- 
nese with English summary)

Teranish1, C. 1916 Yesso red wood ant and late Mr. Yamamura. Insect World, 20: 118-119 (in Japanese)

Teranishi, C. 1929 Japanese ants, their behavior and distribution I. Zool. Mag., 41: 239251 (in Japanese)

Teranishi, C. 1934 Distribution of Formica exsecta var. fukaii and related species. Kansai Konchu Zasshi, 2(2): 5-7, 1 pl. (in Japanese)

Teranishi, C. 1963 Insects of Jehol (VIII) - Family Formicidae. Rep. First Sci. Exped. Manch., Sect. 5, Div. 1, Part 11, 60: 1-12, 5 pls. (in Japanese)

Wheeler, W. M. 1933 New ants from China and Japan. Psyche, 40:65-67

Yano, M. 1912 Slave-making ants and related species in Japan. Zool. Mag., 24: 121-130 (in Japanese)

Yasuno, M. 1963 The study of the ant population in the grassland at Mt. Hakkoda I. The distribution and nest abundance of ants in the grassland. Ecol. Rev., 16: 83-91

* Cited in Collingwood (1976). ** Cited from Morisita (1979) 